Q norden

Internet som arena för hälsoförbyggande arbete 

(2) norden 



\section{Internet som arena för hälsoförbyggande arbete}

Gunilla Jarlbro, Lund i november 2008 


\section{Internet som arena för hälsoförbyggande arbete}

TemaNord 2009:502

(C) Nordiska ministerrådet, Köpenhamn 2009

ISBN 978-92-893-1805-1

Tryck: Ekspressen Tryk \& Kopicenter

Omslagsfoto: ???

Upplaga: 150

Tryckt på miljövänligt papper som uppfyller kraven i den nordiska miljösvanemärkningen.

Publikationen kan beställas på www.norden.org/order. Fler publikationer på

www.norden.org/publikationer

Printed in Denmark

Nordiska ministerrådet

Store Strandstræde 18

DK-1255 Köpenhamn K

Telefon (+45) 33960200

Fax (+45) 33960202

\section{Nordiska rådet}

Store Strandstræde 18

DK-1255 Köpenhamn K

Telefon (+45) 33960400

Fax (+45) 33111870

www.norden.org

\section{Det nordiska samarbetet}

Det nordiska samarbetet är ett av världens mest omfattande regionala samarbeten. Det omfattar Danmark, Finland, Island, Norge och Sverige samt de självstyrande områdena Färöarna, Grönland och Åland.

Det nordiska samarbetet är politiskt, ekonomiskt och kulturellt förankrat och är en viktig partner i europeiskt och internationellt samarbete. Den nordiska gemenskapen arbetar för ett starkt Norden i ett starkt Europa.

Det nordiska samarbetet vill styrka nordiska och regionala intressen och värderingar i en global omvärld. Gemensamma värderingar länderna emellan bidrar till att stärka Nordens ställning som en av världens mest innovativa och konkurrenskraftiga regioner. 


\section{Innehåll}

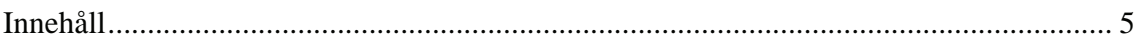

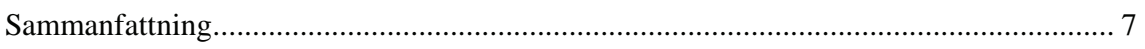

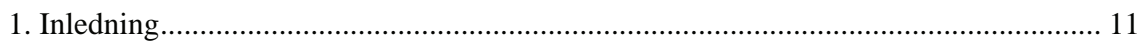

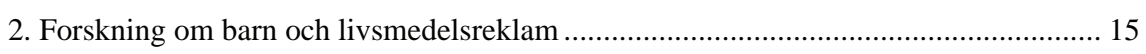

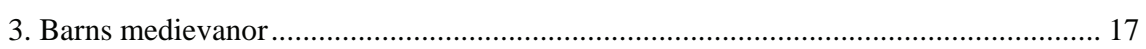

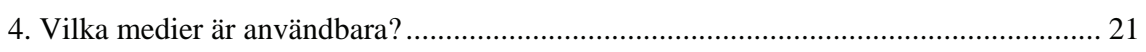

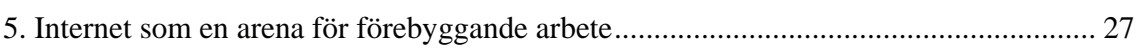

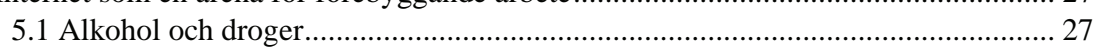

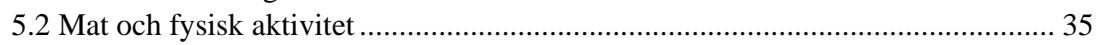

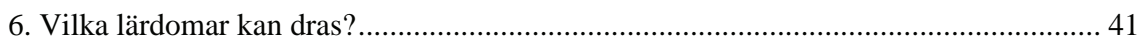

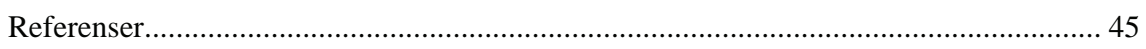

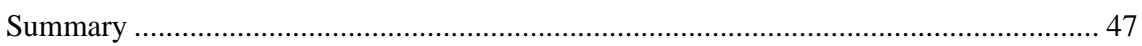





\section{Sammanfattning}

Föreliggande rapport ingår som ett delprojekt inom arbetet med "Realisering av Nordisk Nytte i Kommunikation under Nordisk Ministerråd" rapporten bygger på en s.k. skrivbordsundersökning och dess övergripande syfte är att studera om de kanaler som framgångsrikt användes av kommersiella sändare visavi barn och unga även kan användas i ickekommersiella sammanhang för att få mottagarna att aktivt välja hälsosamma livsstilar. I detta sammanhang menas med unga huvudsakligen åldersgruppen 9-15 år och beträffande hälsoämne kommer fokus att ligga på mat och fysisk aktivitet. De frågor som studien ska försöka besvara är följande:

- Vilka organisationer (statliga och NGOs) i Norden, Europa och annorstädes använder redan s.k. nya medier i sitt hälsokommunikativa arbete?

- Vilka erfarenheter har man dragit av användandet av nya och interaktiva medier? Finns effektutvärderingar genomförda?

- Hur förhåller sig användandet av nya medier såsom webbsidor, communities på Internet visavi "gamla” beprövade metoder såsom användandet av skolan, idrottslärare etc. som vidareinformatörer?

- Kommer användandet av nya medier att öka i hälsoarbetet eller finns det anledning att återgå till "gamla” beprövade metoder såsom undervisning i skolan etc.

Det övergripande syftet med studien är inte att redogöra för alla aktiviteter som genomförts inom området mat och fysik aktivitet utan snarare med hjälp av aktuell teoribildning och forskning inom området resonera fram till ändamålsenliga kommunikationsstrategier för framtiden. Själva undersökningen har genomförts huvudsakligen via sökningar på Internet.

Undersökningen visar att en rad olika myndigheter och NGO:s använder sig av olika interaktiva medier - och då huvudsakligen Internet - i sitt hälsoförebyggande arbete. Vid en genomgång av de aktiviteter som genomförs tycks det mesta vara rent slentrianmässigt användande av kanalen Internet. Det finns få för att inte säga, inga aktörer, som tycks ha genomfört grundläggande mål- och målgruppsanalyser innan man har byggt och sjösatt sina Webbsatsningar. Det finns inte heller några regelmässiga utvärderingar genomförda förutom eventuell besöksstatistik. Man vet med andra ord väldigt lite om vilka effekter de olika satsningarna har och har haft på målgruppens beteenden. Å andra sidan kan man hävda att det troligtvis inte är särskilt kostnadskrävande att bygga en webbsida i jämförelse med t.ex. personlig rådgivning. 
I rapporten ges exempel på mer eller mindre fantasifulla webbsidor som säkert kan upplevas attraktiva för de unga. Problemet är, vilket har nämnts ovan vid flera tillfällen att flertalet av dessa webbsidor är s.k. efterfrågestyrda. Detta innebär att människor först när de känner till ett problem, eller är sjuka blir aktiva informationssökare och då behövs i princip ingen tjusig eller speciell layout. Den aktivt informationssökande individen tar till sig budskapet ändå. Grälla färger och attraktiv layout behövs för att skapa uppmärksamhet för ett specifikt problem. När det gäller kost och fysisk aktivitet och målgruppen är barn och unga i allmänhet är det därför ytterst tveksamt om Internet - oavsett hur mycket spel och chattfunktioner som finns - kan vara effektivt. En ännu inte överviktig ung människa har med andra ord inget behov av att äta rätt och öka sin fysiska aktivitet för att man eventuellt ska förbli frisk och få ett längre liv. Budskap som har en möjlighet att utlösa den önskade handlingen kännetecknas dels av ett enkelt innehåll, dels av att de levereras tidsoch rumsmässigt så nära handlingen som möjligt; s.k. point of action display. Exempel på insatser av detta slag är dekaler, affischer eller s.k. banners på olika webbsidor.

Denna studies övergripande syfte var att utröna om de kanaler som används av kommersiella sändare visavi barn och unga även kan användas i icke-kommersiella sammanhang för att få mottagarna att aktivt välja hälsosamma livsstilar. Skillnaden mellan kommersiell och ickekommersiell marknadsföring är att den förra ofta uppmuntrar människor att göra något, t.ex. köpa en produkt, medan den icke-kommersiella marknadsföringen ofta går ut på att hindra människor att göra något, te.x låta bli att röka, äta sötsaker. Det är alltså lättare att via marknadsföring få människor att göra något än att få dem att låta bli. Belöningen vid kommersiell marknadsföring, dvs. om man följt budskapet kommer omedelbart - man får det man köpt i sin hand. Belöningen för att man cyklar till skolan i ur och skur och äter grönsaker och frukt är inte omedelbar. Vi människor har ofta andra prioriteringar än vad som är fallet för hälsoupplysare, dvs. ett framtida hot rörande ohälsa har ofta mindre betydelse än ett närliggande hot och problem i vardagen.

I Rapporten diskuteras även om det finns anledning att återgå till "gamla" beprövade metoder såsom undervisning i skolan m.m när det gäller kost och fysisk aktivitet? På denna fråga ges svaret både ja och nej. Det hälsoförebyggande arbete som kan bedrivas och bedrivs av skolan, fritidsledare, idrottsförbund etc. bör fortsätta och givetvis erhålla stöd avseende ekonomiska resurser, metoder m.m. samtidigt som man ska satsa på "marknadsföring” i de nya medierna. Om det sistnämnda ska göras är det dock viktigt att "de goda” aktörerna finns på de webbsidor där barn och unga finns, och här gäller det att vara ständigt påläst, såtillvida det som är dagens stora grej kan vara morgondagens flopp. Att vara ständigt uppdaterad och föränderlig är i vårt medielandskap numera ett honnörsord. I rapporten nämns vid flera tillfällen hur olika kommersiella 
aktörer använder sig av s.k. krokar på alla tänkbara webbsidor. Vill myndigheter och NGO:s vara med i detta lopp så måste denna förmåga att lägga ut s.k. krokar utvecklas, dvs. att vara på de Internetplatser där målgruppen befinner sig. 



\section{Inledning}

I juli 2006 antog Nordiska ministerrådet en gemensam handlingsplan för de nordiska länderna rörande bättre hälsa och livskvalitet för medborgarna genom rätt diet och fysisk aktivitet (APN 2006:745). Utmaningen är enorm eftersom medborgarna äter alltmer ohälsosam mat samtidigt som den fysiska aktiviteten bland dem har minskat och följden av detta är problem med övervikt och fetma bland såväl barn och unga som den vuxna befolkningen. Andelen överviktiga vuxna i norden beräknas uppgå till runt 40 procent. Motsvarande siffra för barnens vidkommande uppgår till närmare 20 procent (ibid.). Vidare är det stora skillnader mellan olika befolkningsgrupper, såtillvida att högutbildade äter i större utsträckning en balanserad kost och rör på sig mer än vad som är fallet för lågutbildade medborgare. Det nordiska övergripande målet är således att minska övervikten bland befolkningen samt utjämna klasskillnaderna avseende denna fråga. Ytterligare mål är att få befolkningen i länderna att inse vikten av fysisk aktivitet för välbefinnande. En viktig målgrupp i detta sammanhang är självfallet barn och unga.

För att uppnå målen i den refererande handlingsplanen förespråkas en multisektoriell ansats, såtillvida att såväl myndigheter som NGOs på nationell, lokal, EU samt internationell nivå bör samverka. Den stora utmaningen i detta arbete är av kommunikativ art; hur ska man kunna nå medborgarna och få dem att ta till sig budskapen om sunda matvanor och inse vikten av fysisk aktivitet och framförallt hur ska man få medborgarna att inte bara förstå budskapen utan också följa dem? Självfallet finns det olika sätt att lösa ett samhälleligt problem, dvs. kommunikation är inte det enda sättet. Kurth (1981) nämner "Three Es" som olika samhälleliga styrmedel: Enigineering, Enforcment och Education. Engineering innebär att man åtgärdar den fysiska verkligheten för att komma tillrätta med det aktuella problemet. I vårt fall innebär det att man på olika sätt begränsar tillgängligheten av livsmedel som är ohälsosamt. Det andra sättet att lösa ett socialt problem är genom Enforcement, vilket innebär att man bygger upp ett regelsystem med hjälp av belöningar och bestraffningar och ser till att reglerna följs. I vårt fall skulle det kunna innebära att man lagstiftar om t.ex. åldersgränser vid inköp av vissa livsmedel. Den tredje möjligheten att lösa ett socialt problem är med hjälp av Education, vilket innebär att man med hjälp av utbildning och information försöker få medborgarna att anta det rätta beteendet. Det vanligaste i samband med olika samhällsproblem är att man kombinerar de tre olika E:na. Det bör dock i detta sammanhang nämnas att i samtliga tre E:na finns inslag av kommunikation, men att kommunikationsaspekten är mest renodlad i den åtgärd som kallas Education. Av dessa tre samhälleliga styr- 
medel är dessvärre Education det svagaste av dem alla för att komma tillrätta med ett socialt problem, samtidigt som det inte så sällan är det enda styrmedel som vi har kvar av olika demokratiska, politiska, etiska och moraliska skäl. Vad jag vill ha sagt med detta resonemang är att det är betydligt effektivare att lagstifta och begränsa tillgängligheten av ohälsosamma livsmedel än att försöka påverka medborgarnas hälsa med hjälp av kommunikation. Information och kommunikation är inte det enda vapnet i kampen mot övervikt och fetma, men kanske ett av vårt viktigaste, eftersom det troligtvis inte finns en politisk opinion för att lagstifta och reglera medborgarnas mat- och motionsvanor.

Föreliggande rapport ingår som ett delprojekt inom arbetet med "Realisering av Nordisk Nytte i Kommunikation under Nordisk Ministerråd". Rapporten bygger på en s.k. skrivbordsundersökning och dess övergripande syfte är att utröna om de kanaler som framgångsrikt användes av kommersiella sändare visavi barn och unga även kan användas i ickekommersiella sammanhang för att få mottagarna att aktivt välja hälsosamma livsstilar. I detta sammanhang menas med unga huvudsakligen åldersgruppen 9 - 15 år och beträffande hälsoämne kommer fokus att ligga på mat och fysisk aktivitet. De frågor som studien ska försöka besvara är följande:

- Vilka organisationer (statliga och NGOs) i Norden, Europa och annorstädes använder redan s.k. nya medier i sitt hälsokommunikativa arbete?

- Vilka erfarenheter har man dragit av användandet av nya och interaktiva medier? Finns effektutvärderingar genomförda?

- Hur förhåller sig användandet av nya medier såsom webbsidor, communities på Internet visavi "gamla” beprövade metoder såsom användandet av skolan, idrottslärare etc. som vidareinformatörer?

- Kommer användandet av nya medier att öka i hälsoarbetet eller finns det anledning att återgå till "gamla" beprövade metoder såsom undervisning i skolan etc.

Även om fokus i denna undersökning ligger på mat och fysisk aktivitet kommer även kommunikationsaktiviteter företagna inom andra hälsoområden att diskuteras. Detta för att man ska kunna dra så många lärdomar som möjligt och för att kunna skilja ut de "goda" aktiviteterna från de mindre goda. Det övergripande syftet med studien är inte att redogöra för alla aktiviteter som genomförts inom området mat och fysik aktivitet utan snarare med hjälp av aktuell teoribildning och forskning inom området resonera fram till ändamålsenliga kommunikationsstrategier för framtiden. Själva undersökningen har genomförts huvudsakligen via sökningar på Internet och följande sökord har använts: Youth health, Obesity, young and obesity, healthy food, I am a fat kid, fat children and sport, fat kid that need help to loose weight, against young people using drugs, 
Youth against drug, smoke dop, cannabis forum, m.m. samt dess motsvarigheter på svenska, danska och norska. Vidare har olika länkar som uppkommit på webbsidor följts upp för att kunna spåra ytterligare aktuella webbsidor. Alla kända myndighetssidor som på olika sätt berör livsmedel och hälsa i de olika nordiska länderna har även studerats. Mail- samt telefonkontakt har vidare företagits med personer i de respektive nordiska länderna som har antagits ha kännedom om det som föreliggande rapport handlar om.

Efter detta inledande avsnitt följer en kort sammanfattning av forskning som berör barn och livsmedelsreklam. Därefter följer en redovisning av barn och ungdomars medievanor. I det nästföljande avsnittet ges en teoretisk inblick avseende vilka medier som kan vara användbara i samband med hälsokommunikation. Detta avsnitt åtföljs av en redovisning av hur Internet fungerar som en arena för förebyggande arbete. Ett antal olika webbsidor och communities på Internet som vänder sig till barn och unga gås igenom. Rapporten avslutas med att studiens inledande frågeställningar besvaras. 



\section{Forskning om barn och livsmedelsreklam}

Eftersom denna studies övergripande syfte är att undersöka om man kan använda sig av samma kanaler som kommersiella aktörer för att få barn och unga att anta en hälsosam livsstil kan det vara på plats att studera fenomenet barn och livsmedelsreklam. Kort sagt: lär känna din fiende.

Den mest genomgripande studien inom området barn och livsmedelsreklam har genomförts av Fil. Dr Helena Sandberg, verksam vid Enheten Medie- och kommunikationsvetenskap, Lunds universitet. Projektet har skett i samarbete med Sveriges Konsumenter och med medel från Nordiska Ministerrådet. Hösten 2005 och våren 2007 innehållsanalyserades marknadsföringen av livsmedel, med särskild inriktning på ohälsosamma livsmedel, s.k. skräpmat i följande kanaler; Internet, direktreklam, tvreklam samt barn - och serietidningar. Resultaten av dessa studier återfinns i rapporten Nord 2008:003. Vid en jämförelse mellan de två mättillfällena fann man att andelen reklam för onyttig mat riktad till barn minskat något. Författaren konstaterar dock att även om en minskning skett så ger livsmedelsreklamen fortfarande en obalanserad bild av vad som ska ätas. I studien fann man även att reklamen är svår att identifiera och skilja från det övriga medieinnehållet. Ett förhållande som är giltigt för såväl serietidningarnas annonser, tv-reklam som Internetreklam.

Beträffande Internetreklamen fann man att de hemsidor som kritiserades vid studien 2005 har genomgått innehållsliga redigeringar och ändringar. Författaren tolkar detta som att ägaren av en given hemsida och eller annonsören uppmärksammat projektets resultat och kritik och därmed blivit mer lyhörda för att förändra livsmedelsreklamen till barn. En mindre positiv tolkning av resultaten kan vara att livsmedelsannonsörerna inte får full utdelning av sin satsning på Internet-reklam. Det positiva är dock att man även fann att flera av Internet-annonsörerna i studien från 2007 har börjat med infällda reklamskyltar vilket underlättar för de unga konsumenterna att förhålla sig kritiska och skilja reklam från övrigt medieinnehåll.

Även om denna studie påvisar positiva förändringar mellan de två mättillfällena kan vi dock konstatera att merparten av den livsmedelsreklam som våra nordiska barn utsätts för är reklam för s.k. ohälsosamma livsmedel, dvs. för sött, för salt och för fett. De kommersiella aktörerna är starka och har stora ekonomiska resurser för att motarbeta de folkhälsopolitiska målen i de nordiska länderna. 
Studien Usund Inflydelse av Schultz Jörgensen och Vinderskov (2008) kan även vara på plats att nämna i detta sammanhang. Denna rapport är en s.k. metastudie där aktuella forskningsresultat rörande marknadsföring av s.k. osunda livsmedel riktat mot barn behandlas. I studien framkommer bl.a. att de länder som har mest tv-reklam för s.k. skräpmat också har signifikant högre andel övervikta barn än de länder som sänder lite tvreklam av detta slag. Beträffande nya marknadsföringsformer som är fokus i föreliggande rapport visar Schultz Jörgensen och Vinderskovs rapport att de nya teknologierna för att marknadsföra osunda livsmedel till barn ständigt ökar och att det är svårt för barn att förstå att de utsätts för reklam. Kännetecknande för dessa nya reklamformer är att det görs en sammanblandning mellan reklambudskap och icke-kommersiella budskap. Vidare menar författarna, att en konsekvens av dessa nya marknadsföringstekniker är att den s.k. gate-keeper funktionen som myndigheter, föräldrar m.fl. kan utöva när marknadsföringen sker i de s.k. gamla medieformerna försvinner, eftersom barnen tar emot budskapen i sina egna telefoner eller datorer. Studien visar också att föräldrar överlag har små kunskaper när det gäller hur den s.k. smygreklamen i på Internet eller i mobiltelefoner ser ut. Närmare hälften av danska föräldrar vet överhuvudtaget inte om att det finns gratis spel på Internet med reklambudskap.

Sammanfattningsvis visar dessa två refererade studier att konkurrensen om barnens matvanor är hård och att enorma summor satsas för att locka barnen till sig. De aktörer som vill att barn och unga ska anta en hälsosammare livsstil har för att uttrycka sig krasst hårda motståndare med stort ekonomiskt kapital bakom sig. 


\section{Barns medievanor}

I alla kommunikationssammanhang är den första frågan man bör söka svar följande: Hur kommer jag i kontakt med målgruppen? Detta kan också uttryckas på följande sätt; trots att mitt budskap, t.ex. promenera 30 minuter varje dag, tycks fungera är det meningslöst att annonsera i t.ex. morgontidningen om målgruppen inte har för vana att läsa den. Av denna anledning kan det vara av intresse att studera hur barn och ungas medievanor ser ut. Uppgifterna härvidlag är hämtade från svenska barn, men det är ingen större skillnad i medievanor mellan barn i de nordiska länderna. Innan vi går vidare och diskuterar vidare vilka möjligheter man har att föra ut hälsobudskap till barn och unga via nya interaktiva medier är det alltså av intresse att studera hur användningen av detsamma ser ut.

Den bruttotid som svenska barn (9-14 år) ägnar åt massmedier är totalt 250 minuter per dag (MEDIEBAROMETERN 2007). Denna tid fördelad på olika medier är följande:

$\begin{array}{lr}\text { Television } & 36 \% \\ \text { Internet } & 21 \% \\ \text { Radio } & 14 \% \\ \text { Bok } & 8 \% \\ \text { Video/dvd } & 9 \% \\ \text { Mp3 } & 11 \% \\ \text { CD skiva } & 7 \% \\ \text { Tidskrift } & 3 \% \\ \text { Dagstidning } & 2 \%\end{array}$

Sålunda kan vi konstatera att tv fortfarande - trots hård mediekonkurrens - är det medium som barn i den aktuella åldersgruppen ägnar mest tid åt. Detta illustreras även i tabellen nedan.

Tabell 1. Andel som använder olika medier en genomsnittlig dag (\%).

\begin{tabular}{lrr}
\hline & $\mathbf{9 - 1 4}$ år & 15-24 år \\
\hline tv & 94 & $\mathbf{8 3}$ \\
Internet & 64 & $\mathbf{8 6}$ \\
Bok & 60 & 39 \\
Mp3 & 31 & 56
\end{tabular}

Andel barn i den aktuella åldersgruppen som har tillgång till Internet i hemmet är 86 \% (MEDIEBAROMETERN 2007).

Medierådet i Sverige är en kommitté inom Regeringskansliet som arbetar med barns och ungas mediesituation och med frågor om mediepåverkan. Medierådet genomför även kontinuerliga mätningar rörande 
svenska barns medieanvändning och de resultat som presenteras nedan följer deras senaste rapport avseende denna fråga (Unga \& Medier 2006). I studien har barn mellan 9 till 16 år fått svara på postala enkäter. Tabell 2 nedan visar vad barnen säger sig göra på sin fritid/efter skolan.

Tabell 2 Vad barnen säger sig göra på sin fritid (\%).

\begin{tabular}{lrr}
\hline Träffa kompisar & 74 & 69 \\
Skolarbetet & 56 & 58 \\
Tv, video, dvd & & 30 \\
Sport & & 49 \\
Datorspel & & \\
Internet & 21 & \\
Hjälpa till hemma & 6 & \\
Spela teater/dansa &
\end{tabular}

Av tabellen ovan kan vi sålunda avläsa att barn i betydligt större utsträckning ägnar sig åt kamratliv och skolarbete än att hänge sig åt datorspel och Internet. Drygt $50 \%$ av barn i åldersgruppen 12-16 år säger sig använda Internet varje dag. Motsvarande siffra för de lite yngre barnen (9-12 år) är 25 procent. Frågan är då vad gör barnen när de använder Internet. Svaren redovisas i tabell 3 nedan.

Tabell 3 Aktiviteter som barn gör på Internet (\%).

\begin{tabular}{lr}
\hline Chatta & 65 \\
Spela spel & 59 \\
Surfa för nöje & 35 \\
Mejla & 29 \\
Läxor & 31 \\
Ladda ner & 21 \\
På communities & 12 \\
Lägga ut egna texter & 6 \\
\hline
\end{tabular}

Vidare visar undersökningen att datorspel och Internet är de medier som barn oftast använder på egen hand, dvs. de är ofta ensamma när de spelar eller använder Internet. Vi kan också konstatera att andelen av barnen som är högkonsumenter (använder ett medium tre timmar eller mer per dag) är som följer:

$\begin{array}{lr}\text { tv } & 20 \% \\ \text { Internet } & 16 \% \\ \text { Datorspel } & 9 \% \\ \text { Tv-spel } & 3 \% \\ \text { Video/dvd } & 3 \%\end{array}$

Sammanfattningsvis visar undersökningar över barns medievanor att de chockrubriker som ibland når oss att våra barn och unga sitter dagarna i ända hängda över datorn och glömmer såväl kamrater och skolarbete är kraftigt överdrivna och saknar all vetenskaplig grund. Dessa resultat ställer givetvis även frågan huruvida användandet av s.k. nya interaktiva medier är den bästa kanalen när det gäller att kommunicera med åldersgruppen 9-15 år. Det faktum att kommersiella aktörer flitigt använder sig av dessa kanaler visavi barn och unga är inte detsamma som att det är 
effektivt i bemärkelsen att barn och unga faktiskt tar del av budskapen. Vissa indikationer för detta påstående kan hämtas ur en pågående undersökning vid Enheten för medie- och kommunikationsvetenskap vid Lunds universitet ${ }^{1}$ rörande unga och Internetreklam. Med unga menas i detta sammanhang 15-åringar. I studien har de unga ombetts lista sina favoritwebsidor på Internet och vid en genomgång av dessa kan vi konstatera att inte en endaste av dessa handlade om vare sig livsmedel eller fysisk aktivitet. Inte någon av dessa sidor härrörde heller från någon myndighet eller s.k. frivilligorganisation. 



\section{Vilka medier är användbara?}

Ett genomgående drag hos många hälsokommunikationsprojekt är deras övergripande målformuleringar och målgruppsdefinitioner. Allt för övergripande målformuleringar i samband med förebyggande arbete betyder i klartext att det är svårt, för att inte säga omöjligt, att mäta effekterna av genomförda aktiviteter. I denna publikation kommer jag dock inte uppehålla mig vid vikten av att definiera mål och målgrupper utan föra ett resonemang om medieval, vilket är fokus i denna publikation. I projektet "Realisering av Nordisk Nytte i Kommunikation” kan såväl mål som målgrupper redan anses definierade, såtillvida att målet är att få barn och unga att äta rätt kost samt öka sin fysiska aktivitet och målgruppen är alltså barn och unga. Även om detta övergripande mål behöver brytas ner och en mer detaljerad målgruppsdefinition behöver göras lämnas detta därhän i denna studie.

I samband med att nya medier tillkommer i medielandskapet är det vanligt att entusiasmen tar över och olika aktörer/sändare tror att det nya alltid är det bästa och mest effektiva. Nedan följer en kort beskrivning av forskningsläget avseende faktorer som man bör ta hänsyn till vid val av medium.

Valet av medium i samband med en kommunikationsaktivitet är självfallet avhängigt vilken sändare man använder, vilket budskapet är, vilka som är målgrupp samt vilket ämnesområde som ska behandlas. Olika medier har nämligen olika egenskaper, vars betydelse varierar beroende på vilken kommunikationsaktivitet som är för handen. Det kan dock i detta sammanhang nämnas att man ibland skiljer mellan medium och kanal, såtillvida att medium innebär något mer generellt, t.ex. dagstidningar, medan kanal står för något mer specifikt, t.ex. Dagens Nyheter eller Aftonbladet. I denna framställning kommer dock medium och kanal att användas synonymt.

Vid val av medium är, vilket redan har nämnts, den första frågan man bör söka svar på följande: hur kommer jag i kontakt med målgruppen? Olika medier har, olika egenskaper och i samband med hälsokommunikation står en hel rad medier till vårt förfogande - allt från traditionella massmedier, såsom dagstidningar eller tv till personlig påverkan - var och en med sina fördelar och nackdelar. Följande checklista (Jarlbro 2004) vara till hjälp vid val av medium:

- möjligheten att överföra komplexa budskap

- kostnader

- räckvidd, frekvens och kontinuitet

- antal förmedlare som behövs 
- potentialen för överutnyttjande, dvs. om mättnad kan uppstå så att målgruppen inte uppmärksammar att man vill kommunicera med den

- möjligheten att kunna samordnas med andra medier

- graden av upplevd auktoritet och trovärdighet.

Några av synpunkterna ovan kan kanske behöva förklaras ytterligare. Risken för överutnyttjande kan t.ex. uppstå, om man för ut sina budskap på storbildstavlor och affischer i miljöer där det redan finns mycket av detta - kanske huvudsakligen kommersiella budskap. Ytterligare exempel på risk för överutnyttjande kan t.ex. vara om man har hälsobudskap på kommersiella hemsidor. Följden kan bli att målgruppen pga. mättnad inte ser några budskap överhuvudtaget. Det faktum att olika medier har olika grad av trovärdighet för olika målgrupper, bör man även reflektera över vid val av medium. Tryckta broschyrer där en myndighet står som avsändare har troligen låg trovärdighet för ungdomar som är i riskzonen för t.ex. missbruk.

Flera forskare poängterar hur viktigt det är om man vill att ett budskap dels ska uppmärksammas, dels att en beteendeförändring ska komma till stånd, att man som hälsoinformatör försöker kombinera flera olika medier (se t.ex. Brown och Einsiedel 1990; Lefebvre och Flora 1993; Palm och Sandberg 2004)). Vidare är man överens om att massmedier (såsom radio, tv, dagspress eller Internet) huvudsakligen fungerar när man vill öka kunskapen eller väcka intresse om ett ämne hos målgruppen. Vill man få till stånd beteendeförändringar hos målgruppen är människor ofta det bästa mediet, dvs. interpersonell påverkan.

Ytterligre faktorer som man bör ta hänsyn till vid val av medium är följande:

Räckvidd. Hög räckvidd betyder att en stor andel människor har faktisk möjlighet att ta del av ett budskap. Låg räckvidd betyder sålunda det motsatta. Att välja medium med hög räckvidd - tv-reklam, radio, stortavlor, affischer, annonser i dagspress, Internet m.m. - kan vara en ändamålsenlig och kostnadseffektiv metod, om sändaren vänder sig till stora och vagt preciserade målgrupper som t.ex. "ungdomar” eller medelålders män/kvinnor. Är däremot målgruppen liten, och ytterst detaljerat definierad, kan å andra sidan ett lågräckviddsmedium vara att föredra. Det är dock viktigt att notera i detta sammanhang, att bara för ett medium har hög räckvidd innebär det inte att alla faktiskt har tagit del av ens budskap. Även om Internet har hög räckvidd betyder det således inte att de som verkligen behöver ett specifikt budskap om att äta hälsosam mat m.m. faktiskt ser budskapet ifråga.

Selektivitet. Ett medium som har hög selektivitet, har till skillnad från medier med hög räckvidd, förmåga att selektera ut just den målgrupp man vill nå. Direktreklam - t.ex. att skicka hem information till en åldersgrupp som man vet befinner sig i riskzonen för en viss sjukdom - är mer selektivt än att annonsera i dagspress. Begreppen selektivitet och räckvidd kan 
även användas i samband med ett anti-drogprojekt, eller ett projekt rörande fysisk aktivitet i en skola. Att anordna en temadag där skolans alla elever deltar är sålunda en aktivitet som har hög räckvidd, dvs. alla elever har en faktisk möjlighet att ta del av budskapen. Att en del elever sitter och sover eller spelar luffarschack under tiden informationen ges, minskar inte räckviddstalen. Om vi istället väljer att via personlig påverkan i form av samtal och uppsökande verksamhet påverka de elever som redan har börjat använda droger, eller är i riskzonen för övervikt/fetma, har vi valt ett medium med hög selektivitet.

Fejl! Bogmcerke er ikke defineret.Snabbhet. I samband med olika typer av riskinformation - dvs. nya rön som påvisar ohälsa i samband med någon typ av aktivitet - är snabbhet en viktig egenskap hos ett medium. Radion har i åtminstone Sverige haft en särställning när det gäller att snabbt få ut ett budskap. Andra medier som har egenskapen snabbhet är tv, Internet, flygblad och i viss mån dagspress.

Interaktivitet. Med interaktivitet menas ett mediums förmåga till tvåvägskommunikation. Självfallet har personliga möten människor emellan den högsta graden av interaktivitet. Nya medier som Internet och elektronisk post är emellertid också interaktiva, liksom frågespalter i tidningar.

Uppmärksamhet. De medier som har förmåga att väcka mottagarnas uppmärksamhet, och dessutom samtidigt bibehålla den är, förutom personlig påverkan, film, tv, video och övriga bildmedier. Alla tryckta medier, såsom t.ex. broschyrer, är i princip sämre när det gäller att skapa uppmärksamhet hos mottagarna.

Verkningsgrad. Med verkningsgrad menas ett mediums förmåga att åstadkomma effekt hos mottagaren. Personlig kommunikation är helt klart överlägsen andra medier när det gäller verkningsgrad. För det första kan sändaren vid personliga möten hela tiden avläsa reaktionerna hos mottagaren och fortlöpande anpassa sitt språk och sina budskap efter mottagarnas reaktioner och behov. För det andra kan sändaren bemöta mottagarens argument allt eftersom de kommer upp i diskussionen.

Aterframkallningsmöjlighet. Alla budskap som förmedlas till oss är inte relevanta just då vi erhåller dem, dvs. vi kan behöva återframkalla budskapen/informationen. I detta sammanhang är tryckta medier överlägsna såväl bildmedier som personlig påverkan.

Kontaktkostnad. Med kontaktkostnad menas hur mycket det kostar att nå varje individ tillhörande målgruppen. Inte så förvånande är medier med hög verkningsgrad och/eller hög selektivitet, såsom personlig påverkan, dyra. På motsvarande sätt är medier med hög räckvidd och låg verkningsgrad, t.ex. storbildstavlor, affischer och annonser i dagspress, Internet, billiga.

En sändare kan sålunda använda sig av olika medier som har olika förrespektive nackdelar, när det gäller att åstadkomma såväl uppmärksamhet som att erhålla någon typ av effekt hos mottagaren. Ytterligare en aspekt väl värd att diskutera när det gäller medieval är att studera vem som har 
initiativet i kommunikationsprocessen. Figur 1 nedan redovisar fyra typer av kommunikationsmönster avseende huruvida sändare och mottagare är aktiva eller passiva i kommunikationsprocessen.

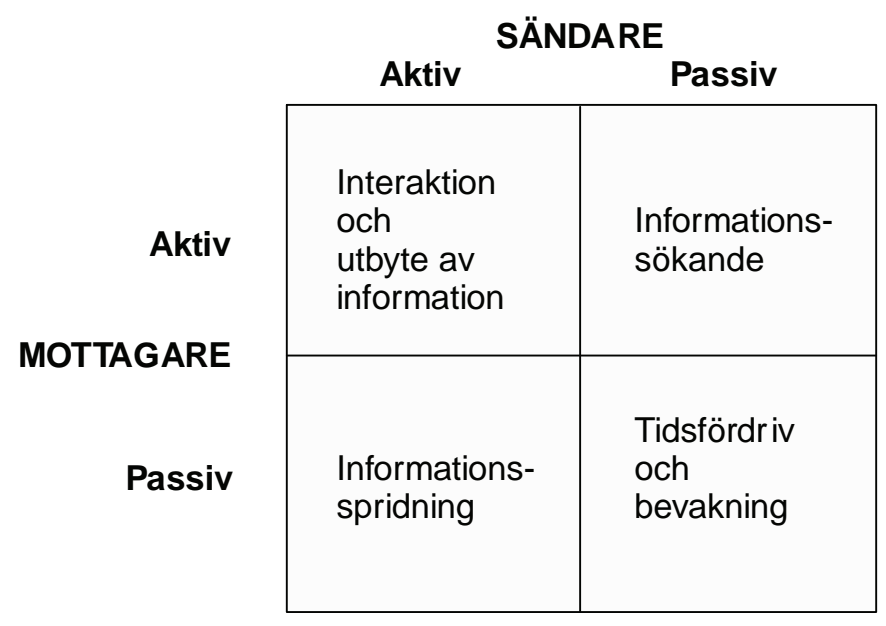

Figur 1 Fyra typer av kommunikationsmönster (modifierad efter McQuail, 1984)

Typologin i figur 1 kan användas när man vill redovisa olika typer av medier i samband med hälsokommunikation. I den övre vänstra rutan finner vi medier som har hög grad av interaktivitet, dvs. som ger möjlighet till tvåvägskommunikation. Här är sålunda både sändaren och mottagaren aktiva parter i kommunikationsprocessen. Exempel på medier eller kanaler är i detta sammanhang personlig påverkan och all s.k. besöksverksamhet och personlig telefonrådgivning. Även broschyrer, där mottagaren ska skicka in en talong, samt olika Internetsidor där frågor kan ställas kan räknas hit.

Informationssökande i figuren ovan innebär att sändaren ställer ett antal kanaler till förfogande och mottagaren får själv söka informationen. Exempel på medier i detta sammanhang är 020-nummer, där informationen är förinspelad på band, hemsidor på Internet och broschyrer som delas ut vid förfrågan.

Motsatsen till informationssökande är informationsspridning. I denna relation är endast sändaren aktiv. Exempel på medier i detta sammanhang är annonsering i dagspress, storbildstavlor, affischer och broschyrer som delas ut till hushåll eller till alla som besöker en viss verksamhet/mottagning.

Kommunikationsmönstret där både sändaren och mottagaren är passiva kan exemplifieras av bl.a. artiklar i dagspress, där sändaren inte varit med och uttalat sig.

I samband med hälsokommunikation, där syftet är att förhindra att ohälsa eller sjukdom uppkommer, är det vanligaste kommunikationsmönstret s.k. informationsspridning, dvs. sändaren är aktiv och mottagaren passiv. I riskkommunikationssammanhang brukar detta förhål- 
lande kallas "informationsbehovsparadoxen" (se t.ex. Jarlbro 2004). Informationsbehovsparadoxen kan kortfattat beskrivas som att människor överlag har en känsla av osårbarhet, vilket gör att det är svårt att informera och få dem att uppmärksamma olika risker, men när något väl har inträffat skapas ett enormt informationsbehov. Översätter vi detta till hälsokommunikationsområdet innebär det att människor är passiva mottagare, när det gäller att kommunicera rörande förebyggande åtgärder. När de väl har blivit sjuka ökar deras informationsbehov och de blir istället aktivt informationssökande.

Det mest optimala är således att såväl mottagaren som sändaren är aktiv i kommunikationsprocessen, dvs. att det förs en två-vägs-kommunikation. För att denna ideala situation ska uppstå krävs emellertid för det första att mottagaren är oerhört intresserad av ämnet och för det andra att sändaren har hög trovärdighet för den aktuella mottagaren.

Den näst bästa situationen är att mottagaren är aktiv och att sändare tillhandhåller relevant information. Detta brukar kallas efterfrågestyrd hälsokommunikation. I framtiden kommer med stor sannolikhet Internet bli det medium som kommer att dominera den efterfrågestyrda hälsokommunikationen. Enligt Vårdbarometern ${ }^{2}$ (2007) har endast $11 \%$ av den svenska befolkningen använt sig av Internet i kontakt med den svenska sjukvården. Motsvarande siffra för år 2006 var 9 \%. Invånarna har i samma studie använt Internet framför allt till att få information om öppettider och tillgänglighet men också för att få råd/ information om sjukdomar, boka eller avboka tid. Exempel på andra efterfrågestyrda Internetsidor är bl.a. den kommersiella webbplatsen NetDoctor, som enligt egen utsaga har 500000 besök, varav 350000 unika besökare per månad. Exemplet Net Doctor kan alltså tjänstgöra som en modell för liknande weplatser från i princip världens alla hörn, där besökaren kan surfa runt och läsa om olika hälsoproblematiker, få svar på frågor och möjlighet att diagnostisera sig själv, delta i debattforum etc. Liknande sidor har de nordiska ländernas olika Cancerförbund och andra patientföreningar. Det som kännetecknar denna typ av sidor är, vilket nämnts ovan, att de är efterfrågestyrda, vilket i klartext innebär att de endast når de redan "frälsta". Detta resonemang kan belysas ytterligare med hjälp av webbplatsen www.infomedica.se, numera www.sjukvårdsrådgivningen.se som beskriver sig själva på följande sätt:

Webbplatsen Infomedica.se är en del av den offentliga vården, den ägs av alla landsting och Apoteket i samverkan. För att markera detta får nu sajten ett mer verksamhetsbeskrivande namn. Från och med 1 oktober är det Sjukvårdsrådgivningen.se som gäller! Webbplatsen är ett utmärkt exempel på hur offentlig verksamhet kan gå ihop och föra ut samordnad information till allmänheten. Cirka 16 000 användare per dygn besöker sajten. Flera enkäter och utvärderingar visar att

\footnotetext{
${ }^{2}$ Vårdbarometern är en rullande befolkningsundersökning som genomförs i nästan hela Sverige. Med hjälp av Vårdbarometern kan den vuxna befolkningens erfarenheter av, kunskaper om och attityder till hälso- och sjukvården kontinuerligt avläsas.
} 
användarna tycker att den är en mycket bra informationskanal. Det bekräftas också av de priser och utmärkelser som webbplatsen fått under åren - till exempel Nationalencyklopedins Kunskapspris, Sveriges bästa hälsosajt och Guldlänken för Bästa offentliga webbplats. Men kännedomen om webbsidan är låg - alltför få känner till denna möjlighet att få bra hälsoinformation.

I det följande avsnittet ska ett antal interaktiva hälsoprojekt i såväl Norden som övriga världen redovisas. Redovisningen gör inte på något sätt anspråk på att vara heltäckande utan ska snarare ses som en exempelsamling på såväl goda som mindre genomtänkta projekt. 


\section{Internet som en arena för förebyggande arbete}

Ovan nämndes att när nya medier tillkommer så blir entusiasmen stor bland såväl kommersiella som icke- kommersiella aktörer och i princip alla ska använda det nya. Detta märks tydligt i samband med denna undersökning, dvs. det formligen vimlar av mer eller mindre fantasifulla hemsidor som ska väcka intresse och fånga de unga. I det följande kommer ett antal exempel på interaktiva webbsidor att presenteras. Presentationen är fördelad på olika hälsoområden.

\subsection{Alkohol och droger}

Ett svenskt och numera avslutat hälsoprojekt är Alkoholkommittén ${ }^{3}$ vars övergripande syfte var att minska alkoholkonsumtionen bland unga medborgare. I projektet arbetade man såväl med "gamla" beprövande insatser såsom stödverksamhet till kommuner, föräldrarinformation, opinionsbildning m.m. samt med nya interaktiva medier visavi målgruppen unga vuxna. För denna undersökning är det intressant att studera den s.k. alkoholprofilen som var ett webbaserat testinstrument uppbyggt på 13 frågor om bland annat motivationen att ändra sina alkoholvanor. Efter att ha svarat på de frågor som ställdes fick man ett svar, en "feedback" som tog upp både nuläget och framtiden, t.ex. "Vad riskerar att hända om jag fortsätter att dricka på det här sättet och med min bakgrund?”. Testet tog ca tio minuter och kunde ge mer än 3000 olika svar. Enligt utvärderingar fick Alkoholprofilen en närmast succéartad start. Från lanseringen i början av november 2003 till två månader senare hade sidan haft drygt 450 000 unika besökare och 340000 personer hade gjort testen och fått en återkoppling. Av dessa var ca 240000 personer i den primära målgruppen, 18-25 år. 2007 hade antal besökare sjunkit till under 100 000. Hur kunde denna satsning få ett sådant initialt genomslag i målgruppen? Svaret på denna fråga är den enorma massmediekampanj som föregick lanseringen av webbsidan. Mediekampanjen bestod bl.a. av nio olika reklamfilmer som visades i flera kommersiella tv-kanaler och på biografer. Vidare marknadsförde man sig på flera kända kommersiella webbsidor samt hade radioreklam och uppsökande verksamhet där dekaler delades ut. Satsningen för att målgruppen skulle hitta den aktuella webbsidan var

\footnotetext{
${ }^{3}$ Alkoholkommittén var verksam åren 2001 till 2007.
} 
enorm och tog även stora ekonomiska resurser i anspråk. Flera olika utvärderingar genomfördes och de visade att kännedomen om webbsidan var stor, men att den knappast påverkat målgruppens alkoholkonsumtion (Alkoholkommittén 2001-2007. Slutrapport).

Erfarenheter från denna s.k. Internetsatsning visar tydligt att man måste genomföra stora massmediekampanjer för att målgruppen ska hitta till den aktuella webbsidan. När målgruppen väl hittat dit och använder sig av den aktuella informationen upplever den ofta stor belåtenhet med det som bjuds, vilket alkoholprofilens utvärderingar tydligt visade.

www.yad.fi (Youth against Drugs) är en Finländsk websida som särskilt bör nämnas eftersom de använder sig av samma design som raveclubar använder. Rave-clubar har som bekant blivit hårt kritiserade för sin toleranta inställning till droger. Genom att använda sig av samma design kan man alltså "lura” de unga att hitta sidan som de vid första anblick kan tro stå för någonting annat.

Bakom webbplatsen www.drugsmart.com står CAN, Centralförbundet för alkohol och narkotikaupplysning. På webbplatsen finns olika tävlingar, spel och chattfunktioner. Det är tydligt att hemsidan riktar sig till ungdomar, webbplatsen har lite av en "serietidningslook" för att det ska se häftigt ut. På sidan finns information om ett projekt som heter "local hero" vilket innebär att om man är en grupp ungdomar så kan man genomföra ett drogförebyggande projekt. För att bli local hero krävs att ungdomarna deltar i en workshop - Workshop Mot Knark. Två processledare från Local Hero är knutna till varje ungdomsgrupp. Processledarna kommer till en s.k. Local Hero-grupp och jobbar tillsammans med ungdomarna initialt. Processledarna finns sedan som ett pedagogiskt stöd, och som kan inspirera och förbereda inför ungdomarnas egna självständiga arbete. På hemsidan finns material att ladda ner när gruppen kommit igång, såsom verktyg kring projektplaneringen, projektutvärdering och projektansökan. Det finns en arbetsbok med tips och metoder för kartläggningen av gruppens närmiljö vilket gruppen ska göra enligt local hero projektet. Boken innehåller information som är tänkt att inspirera gruppen och även övningar som är tänkt att göra det lättare att planera projektet. En tolkning av syftet med local hero-klubben kan vara att ungdomarna dels ska sprida bra budskap till andra ungdomar, dels att om ungdomarna är med i local hero så lägger de tid på engagemanget och håller sig undan droganvändning själv. Detta projekt kan ses som ett exempel på en till synes genomtänkt strategi, dvs. sändarna - i detta fall CAN - har insett vikten av att ju känsligare ett ämne är för mottagarna, desto större vikt läggs på sändaren. Detta kan också uttryckas på följande sätt; fel sändare och budskapet förkastas av mottagarna.

I vissa sammanhang går det alltså inte att använda myndigheter eller andra auktoriteter som sändare. När så är fallet kan en lösning vara vad vi brukar kalla för peer-education, vilket ibland översätts med termen kamratfostran. Projektet ovan tycks använda sig av denna strategi. Det 
engelska ordet peer översätts - enligt min åsikt - bäst med ordet jämlike och i detta sammanhang betyder sålunda peer-education helt enkelt att jämlike undervisar eller informerar jämlike. Fördelen med att låta en "jämlike” eller, om man heller vill, någon som tillhör den egentliga målgruppen agera som sändare, dvs. förmedla budskapet är, att denna förmodas ha ett stort mått av kulturkompetens. Om sändaren är lik målgruppen ur sociokulturellt hänseende förväntas denne känna till vilka normer, värderingar och attityder som råder hos målgruppen. Denna kunskap gör att sändaren t.ex. kan formulera budskap på rätt känslo- och språknivå.

Att använda peers som sändare är en väl beprövad metod i samband med sex- och samlevnadsinformation i allmänhet och i samband med hiv/aids-information i synnerhet. Det finns dock inga undersökningar som visar att denna metod skulle vara särskild användbar i samband med drogförebyggande arbete. Det finns nämligen en fara i att använda s.k. peers som sändare, dvs. de som rekryteras för ändamålet blir en elit i sin egen organisation och kan därför på sikt minska sina möjligheter när det gäller att utöva inflytande inom den egna gruppen. Om man ska välja en expertsändare eller en s.k. peers som sändare är beroende av dels vilket ämne som är för handen, dels vilket kommunikationsmål - kunskapsmål, attitydmål eller beteendemål - som har satts och slutligen hur målgruppen har definierats. I samband med kommersiell marknadsföring brukar vikten av att ha "kändisar" som sändare betonas. Det finns även gott om icke-kommersiella kampanjer, där man valt att ha en känd artist eller idrottsstjärna som sändare . Om vi ska välja en sändare som är så lik de personer vi har för avsikt att påverka, eller ska välja en sändare som mottagarna ser upp till och beundrar, avgörs återigen av såväl de kommunikationsmål som vi har satt som av hur vi har definierat vår målgrupp.

GLÖD - www.glod.com - är en ungdomstidning som ges ut av Statens folkhälsoinstitut, Sverige och kommer ut fem gånger per år. GLÖD riktar sig till läsare mellan 13 och 19 år. Upplagan är 100000 ex. GLÖDs syfte är att stärka ungdomars självkänsla, identitet och hälsa. GLÖD skriver om existentiella frågor som kärlek, sex, vänskap och relationer. Den är ett komplement till skolans sex- och samlevnadsundervisning och belyser också psykologiskt känsliga frågor. GLÖD strävar hela tiden efter att sätta in sex- och samlevnadsfrågor $\mathrm{i}$ ett större livssammanhang. GLÖD är gratis, mottagaren betalar bara för porto. Glöd beställs huvudsakligen av skolor och ungdomsmottagningar. Den finns också på fritidsgårdar, behandlingshem och bibliotek runt om i landet. GLÖD hämtar uppslag till tidningen från samtal med ungdomar. Vid mötena får var och en ge förslag på sådant som de skulle vilja läsa om. Efter en genomgång väljs några ämnen ut och diskuteras mer ingående. En fast referensgrupp av ungdomar läser alla texter och säger sin mening innan GLÖD går i tryck. De deltar också under layoutperioden. När en tidning har kommit diskuteras innehållet med referensgruppen och andra ungdomar. På webbsidan finns debattforum, frågelåda och nyheter relaterade till ung- 
domar. Glöd kan tjänstgöra som ytterligare ett exempel på fenomenet peer-education.

IOGT-NTO som är en frivillig organisation inom nykterhetsrörelsen står bakom sidan www.junis.org. Sidan har webbkryss, tävlingar, spel och en webbklubb. Man kan även ställa frågor om alkohol genom sidan. Sidan är attraktiv med en genomtänkt lay-out. Frågan är dock hur hittar de unga dit?

IQ - www.iq.se - är ett dotterbolag till Systembolaget AB, Sverige . Syftet med IQ:s verksamhet är verka för ett smart förhållningssätt till alkohol - att skapa en förändring av attityder och beteende i samhället som resulterar i minskad alkoholkonsumtion och därigenom minskade alkoholskador. Det är dock tveksamt om någon annan än de redan s.k. frälsta når denna sida. Den danska motsvarigheten till denna sida är www.goda.dk. Bakom denna sida står Föreningen Gode Alkoholdninger, GODA, som finansieras av Foreningen af Danske Spiritusfabrikanter och Vin og Spiritus Organisationen i Danmark (VSOD). Syftet med GODA är detsamma som den svenska motsvarigheten, dvs. att främja en god alkoholkultur för att på så sätt motverka och minska missbruk. Aktörerna bakom GODA har goda intentioner oaktat bakgrunden och den danska webbsidan är betydligt mer attraktiv för unga än vad som är fallet för den svenska motsvarigheten. Hur välbesökta dessa sidor är vet vi ingenting om men fenomenet sändarartrovärdighet kan i detta sammanhang aktualiseras, dvs. hur trovärdigt är det att organisationer som har sin utkomst på att sälja alkohol samtidigt vill begränsa konsumtionen av detsamma.

En norsk sida www.avogtil.no/ vars huvudmän är frivilliga organisationer och som handlar om att få unga att ej dricka alkohol kan tjänstgöra som exempel på en typisk informationswebsida, dvs. med ungdomlig design men inte särskilt interaktiv.

Ungdom mot narkotika är en organisation - www. umn.no/ - som i sin tur består av flera olika organisationer såsom partipolitiska ungdomsförbund och Norges Röda korset. Sidan är attraktiv i sin utformning men inte interaktiv. En betydligt mer interaktiv sida är www.diil.no, som är statligt finansierad och har en massa olika aktiviteter vars syfte är att få unga att vara nyktra ett helt år. Följande beskrivning finns:

Rusfri Diil er et rusforebyggende ungdomsprosjekt for og med ungdommer i alderen 13-18 år. Du gjør en diil om å være rusfri i ett år og Rusfri Diil skaffer deg gode grunner! Poenget med Rusfri Diil er ganske greit. Vi veit at jo seinere du prøver alkohol og andre rusmidler, jo mindre er sjansen for at det blir et problem for deg siden. Vi er ikke ute etter å gjøre deg totalavholds for resten av livet (blir du det, er det helt greit for oss... ;-) ), men å ta ett år av gangen. Du gjør diilen. Det er ingen der til å passe på deg, men bare en hel haug med andre diilere over hele landet som backer deg opp. Diilen er din personlige greie. Du kan skrive det på fingern din, eller aldri si det til noen. Det er opp til deg. Sosial- og helse- 
direktoratet er de som gir oss penger for å drive med diilen. Det er ingen som tjener noe på det, bare deg selv og huet ditt. Nykter hele året!

En brittisk sida väl värd att nämna är www.parentsusingdrugs.org.uk. Denna sida erbjuder huvudsakligen yngre barn som lever med missbrukande föräldrar hjälp och stöd. Tonen i sidan är personlig men ändå vuxen. Barnen får veta att de inte är ensamma om att ha s.k. problemföräldrar. De kan fråga vuxna och sidan har såväl spel som erbjudande om möjligheter till att teckna och lägga ut sina bilder. Organisationen som står bakom denna sida beskriver sig själva på följande sätt:

The purpose of the Department for Children, Schools and Families is to make England the best place in the world for children and young people to grow up. We want to:

- make children and young people happy and healthy

- $\quad$ keep them safe and sound

- give them a top class education

- help them stay on track.

Den norska sidan https://www.barnogunge.no/ kan sägas vara en motsvarighet till den föregående, dvs. vänder sig till barn som har missbrukande föräldrar. Sidan har allvarlig lay-out och har inget annat syfte än att nå de unga som behöver information och hjälp. Dessa två sidor kan sägas vara efterfrågestyrda, dvs. de unga har redan ett problem och kan därför aktivt söka efter hjälp och stöd.

Ytterligare en sida värd att nämna är från Australien och organisationen The Australien Drug Foundation www.adf.org.au. Denna sida appellerar troligen inte till unga direkt utan är mer av en allmän informationssida för vuxna såsom föräldrar och lärare. Via denna sida kan man dock komma vidare till www.somazone.com.au som har en betydligt ungdomligare design och belyser en rad olika hälsoproblem. Sidan är till för de unga och ger även sken av att det är unga som såväl designat som skrivit den. Ungdomarna har själva möjligheter att lägga ut berättelser samt få svar på olika hälsorelaterade frågor. Hur välbesökt sidan är vet vi dock ingenting om. Inte heller vet vi hur denna i och för sig utomordentliga sida de facto marknadsförs.

Via den brittiska sidan www.d-2k.co.uk/ kommer man till http://www. talktofrank.com. Talktofrank är riktad till ungdomar som själv har eller har vänner som testar droger eller redan är beroende. På sidan finns filmmaterial om olika droger, möjligheter att få svar på frågor etc. Sidans lay-out är mycket attraktiv och ungdomlig. Antal besökare vet vi ingenting om och det kan finnas en risk att sidan snarare väcker nyfikenhet för droger än förebygger användning av detsamma. Problemet med dessa i och för sig intressanta sidor ur ett kommunikationsperspektiv är att de är baserade utifrån en myndighetswebsida och vi har inte funnit länkar till dessa sidor på kommersiella sidor som kan tänkas attrahera ungdomar i 
första hand och sedan få dem att klicka vidare. Återigen ser vi att problemet snarare verkar vara av marknadsföringsmässig art än det faktum att sidan i sig är bristfällig.

www.sada.org från USA kan tjänstgöra som en ganska typisk Internetsida som har såväl föräldrar, lärare som studenter som sin målgrupp. Organisationen som står bakom beskriver sig själv som a non profit community service organization serving student for their future. Sidan är inte särkilt interaktiv utan här kan man få svar på frågor om droger samt boka föreläsare som man vill ska komma och prata för de studerande. Att jag nämner denna sida är mest för den är ett exempel på hur många organisationer mer eller mindre slentrianmässigt bygger en webbsida utan att fundera över några som helst kommunikationsstrategier såsom hur når vi målgruppen, vilka budskap ska vi ha osv.

www.skateagainstdrugs.org kan sägas vara den föregående nämnda sidans motsats, såtillvida att man har en mer detaljerad målgrupp, dvs. ungdomar som åker skateboard. Sidans layout är dock tämligen grå, men styrkan är att organisationen som står bakom - en s.k. frivilligorganisation - sponsras av såväl kända skateboardåkare som företag som tillverkar skateboard med dess tillbehör. Det faktum att kända skateboardåkare finns med på sidan inger troligen förtroende samt ökar budskapens genomslagskraft för målgruppen.

Jag har ovan nämnt att det stora problemet med hälsobudskap på Internet är att finna de aktuella webbsidorna. Det räcker alltså inte med att en enskild webbsida i och för sig är genomarbetad och att budskapen är bra för den aktuella målgruppen om målgruppen inte kan hitta till webbsidan. Nedan följer ett exempel på vilka steg man kan får tag för att komma till en ungdomssida:

ACYS is a not-for-profit project funded by the Australian Government through the Department of Families, Housing, Community Services and Indigenous Affairs www.acys.info/about/. Här hittar man följande länk: www.turningpoint.org.au/ (Turning Point is part of the International Network of Drug Treatment and Rehabilitation Resource Centres for The United Nations Office of Drugs and Crime (UNODC) and is a member of the International Harm Reduction Association.) Via denna sida kommer man till följande sida: www.drugpoint.org.au/index.htm som har bra layout och är riktad till unga som kan ställa frågor och få information. De har även en tecknad film http://www.turningpoint.org.au/e\&t/Opie\% 20website\%20preview/Opie\%20website\%20preview.htm.

Man får med andra surfa runt rätt ordentligt innan man hittar rätt. Och det finns ytterst få s.k. krokar från dessa hälsosidor på kommersiella sidor, vilket definitivt inte är fallet för andra aktörers agerande. I samband med marknadsföring av musikfestivaler och andra evenemang är t.ex. de drogvänliga aktörerna samt kommersiella aktörer oerhört fantasifulla när det gäller att "sälja" sina webbsidor och budskap, dvs. krokar finns överallt. Följande sidor är ett exempel på detta resonemang www.weedfarmer. 
com/top100/, marijuananews.com/blog/. De icke-kommersiella aktörerna skulle kunna använda sig av samma strategier, dvs. marknadsföra sig på de sidor som unga människor i allmänhet och de som kan vara i riskzonen i synnerhet de facto besöker.

www.ama.com.au/youth/code/cannibis.html (AMA -Australien Medical association) har utvecklat en sida som vid första anblicken liknar olika pro-cannibisforum (och det finns gott om dem) via sin layout och formspråk. På denna sida behandlas en rad olika hälsoproblematiker, bland annat livsmedel och fysisk aktivitet. Tonen på sidan är positiv, dvs. man förespråkar fördelarna med att uppta det rätta beteendet. Denna sida kan tjänstgöra som ett gott exempel på hur man via layout försöker få de unga att hitta och fastna vid sidan. Sidan kan också tjänstgöra som ett gott exempel på hur varsam man är när det gäller budskapets ton. Detta om budskapets ton kan behöva utvecklas något. På frågan om man ska använda sig av sakliga eller känslomässiga budskap finns egentligen inget entydigt svar. Rationell argumentering brukar lämpa sig bäst om mottagaren redan är motiverad och intresserad av ämnet, medan emotionell argumentering passar bäst för att nå de ointresserade. Beträffande skrämselargumentering påpekar flera forskare (se t.ex. Reardon 1989; Witte 1995) att för mycket skräck leder till förnekande, dvs. mottagaren vill överhuvudtaget inte ta del av budskapet. Även en mindre grad av skrämsel kan leda till förnekande hos mottagaren. Detta sker när budskapet saknar anvisningar om hur mottagaren ska agera för att undvika problemet. Lösningen på denna problematik är enligt Reardon:

To avoid this problem, media messages that include fear should be folllowed by face-to-face opportunities to discuss strategies for reducing risks for Aids that in turn reduce fear as well as denial. (ibid. 286)

Även Witte (1995) anser att skräckbudskap kan vare effektiva, men endast då budskapet kombineras och balanseras med budskap som ger individen en upplevd handlingskontroll, s.k. self-efficacy . Sammanfattningsvis kan man säga att om ett skräckbudskap ska vara effektivt måste det dels innehålla information om ett faktiskt och möjligt hot samt information om målgruppens sårbarhet när det gäller hotet, dels information om målgruppens möjligheter att följa budskapets rekommendationer och hur man faktiskt reducerar eller eliminerar hotet.

Vid en genomgång av olika hälsowebsidor kan man konstatera att när olika myndigheter eller NGO:s har försökt att nå en bred allmänhet med budskap rörande ohälsosamma aktiviteter har man i sina budskap förlitat sig på endast två strategier; skrämselargument eller en saklig presentation av fakta. Den kommersiella marknadsföringen, till skillnad från den ickekommersiella, har valt en helt annan väg när det gäller att påverka människor. Kommersiella aktörer tenderar att undvika såväl negativa som rationella budskap utan fokuserar istället på det positiva i livet.

Emellertid måste det återigen betonas att det trots allt är en viss skillnad mellan att marknadsföra tvål och schampo och att ändra människors 
kostvanor. Poängen med resonemanget ovan är dock att man även i samband med hälsobudskap kan ha en positiv ton och betona fördelar istället för nackdelar, t.ex. istället för att säga "om du röker blir du sjuk" kan man säga "om du låter bli att röka förblir du frisk". Positiva budskap har bl.a. visat sig uppmuntra människor till en förändring. Vidare bidrar positiva budskap till att människor ser fördelarna med ett hälsosamt beteende samt att oro och omotiverad rädsla minskar. Nedan följer en rad olika omständigheter som avgör när och hur man ska använda positiva budskap:

- När ämnet är okänt för målgruppen, använd känslomässiga positiva budskap i form av jämförelser mellan olika beteenden, demonstrationer och s.k. vittnesreklam.

- Använd indirekta positiva budskap när mottagarna är familjära med såväl ämnet som kampanjen. Humor och andra positiva känslor är ofta effektiva när man vill slippa selektiv uppmärksamhet beroende på att mottagarna är uttråkade och har blivit utsatta för en överexponering av ett budskap.

- Var försiktig med att använda positiva budskap om ämnet är associerat med starka negativa känslor. Det är svårt att använda positiva känslor för att förändra starkt negativa attityder.

- Använd positiva budskap när du vill ändra kampanjens fokus. När det är viktigt att få mottagarna att ändra synsätt eller perspektiv på ett ämne kan positiva budskap vara effektiva, för att ändra mottagarnas mentala referensram.

- När du vill öka samtycket hos mottagarna är positiva budskap bättre än negativa, eftersom de ger mottagaren en känsla av kontroll över ämnet snarare än hjälplöshet.

- När mottagarna är obeslutsamma och förvirrade (vilket ofta kan vara fallet i samband med hälsofrågor) är positiv påverkan en excellent strategi.

Sammanfattningsvis visar vid en sökning på droger, alkohol m.m. att det finns hur mycket som helst på Internet, dock en ganska begränsad mängd från aktörer som vill öka hälsan bland de unga. Vidare visar många även genomarbetade webbsidor - att de troligen är svåra för unga att hitta eftersom de ofta måste sökas via någon form av myndighetssida eller NGO-sida. Detta kan också uttryckas som att många av dessa sidor enbart når de redan s.k. frälsta. Kommersiella aktörer är betydligt bättre, vilket redan har nämnts att sätta ut krokar på alla möjliga webbsidor som man redan vet har många besökare av unga. Likaså lyser drog- och alkoholförebyggande aktörer med sin frånvaro på Youtube och communities typ Facebook m.fl.. 


\subsection{Mat och fysisk aktivitet}

I det föregående gavs exempel på såväl lyckade som mindre lyckade Internet-satsningar avseende alkohol- och drogförebyggande arbete. Vad man kan konstatera är att det finns gott om aktörer inom detta hälsoområde. När det gäller området mat och fysisk aktivitet är dessvärre Internet inte fullt så belamrat av dessa frågeställningar, dvs. vilket dels kan tolkas som att fetma bland barn och unga inte anses lika skadligt som alkohol och droganvändning eller att frågan är känslig. Vi har inte funnit något forum där barn med övervikt kan vända sig till och få svar på sina frågor. Nedan följer dock ett axplock av lite olika webbsidor som på olika sätt försöker förebygga ohälsa bland unga.

www.ungdomar.se är en svensk sida som vänder sig till ungdomar angående hälsa (i generella termer). Denna sida är ett exempel på ett lyckat försök eftersom webbplatsen innehåller bl.a. nytt om arbeten vilket innebär att det finns andra (inte hälsoproblem) ämnen som gör att ungdomarna kommer till webbsidan. Problemet är ju som vi diskuterat tidigare att ungdomarna inte hittar till förebyggande hälsowebsidor, och av denna anledning kan det vara bra om man vill nå de unga att ha angelägna s.k.dragplåster. På denna sida finns bl.a. chatt, diskussionsforum, bloggar samt fotoalbum. Bakgrunden till denna sida är som följer:

Hösten 1999 togs initiativet till att bygga en sajt på nätet där specialistutbildade experter som läkare, psykologer, barnmorskor, SYOkonsulenter etc. kunde svara på anonyma ungdomars frågor rörande bl.a. kroppen, sexlivet, kompisar, föräldrar, utbildningar, jobb etc. Sajten kom att heta Ungdomsmottagningen.com (sedermera Ungdomsmottagningen.se) och öppnade för allmänheten den 4 september 2000. Sajten växte därefter i mycket snabb takt med att allt fler nyfikna och undrande ungdomar hittade hit. Sajten Ungdomar.se startades i november 2003. Denna sajt var en allmän mötesplats för just ungdomar och innehöll forum, nättidningen Edition, tävlingar etc. I november 2005 slogs bägge dessa sajter samman och från om med augusti 2006 heter sajten bara Ungdomar.se. Medlemmarna är i åldern 13-30 år med en snittålder på 18 år. Tjejerna utgör 59 \% medan killarna utgör 41 \% av den totala målgruppen.

Projekt Versus - www.projektversus.se - är ett treårigt ungdomsprojekt som drivs med stöd från Allmänna Arvsfonden. Det övergripande syftet är att förebygga övervikt bland ungdomar.

Det här projektet riktar sig mot ungdomar (delvis) men får anses vara ett exempel på en mindre genomtänkt websatsning. Det finns en noshörning (osäkert om det är logotypen) där ungdomar ska trycka och då kommer det upp reklam för vattengymnastik. Noshörningar får väl anses vara gulliga djur, men det är mer tveksamt om man som ung vill förknippas med en. Projektet beskriver själv sitt syfte på följande sätt:

Syftet är att förebygga fysisk och psykisk ohälsa hos överviktiga barn och ungdomar. Delmålen är att höja kunskapen i målgruppen om övervikt 
och dess konsekvenser, öka insikten och förmågan att själva aktivt förebygga övervikt och att öka målgruppens förmåga till nyttigare kostintag samt fokusera på betydelsen av motion.

Projektet bygger på ett kommunikationskoncept som använder en kombination av breda kommunikationskanaler som film och skolwebb och ett ungdomsnätverk som kommunikatör.

Den svenska Utbildningsradion har en speciell ungdomssida där unga kan de diskutera ämnen som kärlek, film och hållbar utveckling, göra olika tester och chatta med experter om sex och relationer - www.ur.se/Ung/Amnen/ Halsa/. Även på denna sida - www.ur.se/Ung/Program/Ramp/ -kan de unga få svar på olika hälsorelaterade frågor. Huruvida de unga själva hittar till denna sida är mer tveksamt, men det finns möjligheter att sidan marknadsförs via den svenska skolan som brukar använda sig av Utbildningsradion program. . Liknande sidor har Danmarks radio -www.dr.dk/boern - samt Finlands radio www.ohjelmaopas.yle.fi/sisaltooppaat/lapset/.

Den svenska sidan sjukvårdsrådgivningen har även en anpassad sida för små barn med olika djur som de kan trycka på. Sidan är ett lyckat barnanpassat exempel, men förutsätter givetvis att vuxna leder de små barnen till sidan

Ytterligare ett exempel på s.k. efterfrågestyrd information är sidan www.rodasidorna.se. Sidan har inga interaktiva metoder eller liknande utan är helt enkelt en sida där det finns tydliga länkar till hjälp som ungdomar kan få. Sidan vänder sig till ungdomar t.o.m. 18 år. Sidan presenteras på följande sätt:

Röda Sidorna är en sökmotor för unga, en slags telefonkatalog för de som behöver stöd av kunniga och engagerade vuxna. Sidan är skapad av BRIS - Barnens Rätt I Samhället. Den är till för dig som inte är äldre än 18 år. Här finns information som visar var du kan få hjälp när det känns svårt och ensamt. Med sökmotorn kan du själv hitta den hjälp och det stöd som finns för dig - lokalt eller rikstäckande. Här finns allt från mötesplatser där du finner någon som är eller varit i samma situation som dig, till en pålitlig vuxen du kan tala med, till direkt hjälp om du råkat ut för övergrepp eller liknande. Du kan söka på kommun, problemområde, verksamhetens namn samt via ett eller flera sökord. På Röda Sidorna är du alltid anonym.

Den norska motsvarigheten till denna sida kan www.ung.no/oss/ helse/12390.html sägas vara. På sidan ges möjlighet att chatta och tävla etc.

Matrock - www.matrock.se/- är ett svenskt projekt vars övergripande syfte är att få mat att vara häftigt därav att de benämner det som rockigt. Poängen är att man vill få ungdomar att bry sig om mat, att äta nyttigt etc. De som står bakom matrock är privatpersoner som samarbetar med kommuner och landsting. Idén är bra, dock är det bara logotypen som är ungdomlig och lite "rockig" och inte resten av webbsidan. Projektet beskriver sig själv på följande sätt: 
Vi vill ge ungdomar ökad insikt för en förändrad attityd och på sikt ett förändrat beteende mot bättre levnadsvanor, utifrån perspektivet: mat, motion/rörelse, psykisk hälsa och välbefinnande.

MATROCK $^{\circledR}$ är ett unikt riksomfattande projekt över 3 år där Mat, Hälsa, Rörelse och Glädje står i fokus. Högstadie- och gymnasieungdomar är målgruppen och framtidens konsumenter!

Ohälsa, Övervikt, Fetma, dåliga Matvanor, för lite av fysisk aktivitet samt allt mindre tid för glädje och njutning i tillvaron, är sanningar vi dagligen påminns om. Det börjar bli bråttom, att öka människors och ungdomars medvetande om att det största ansvar man har är att "a hand om sig” få nya perspektiv på tillvaron och livet!

MATROCK $^{\circledR}$ erbjuder ökad kunskap och konkreta verktyg som kan medverka till - förändrade vanor och beteenden - ny livsstil och bättre hälsa - ökad prestation via rörelse och motion samt via rytm och dans ge livet ny puls! MATROCK ${ }^{\circledR}$ ger upplevelser för livet samt också roliga och häftiga utmaningar!

Danska födevarelsestyrelsen har på sin webbsida www.altomkost.dk ett test där såväl barn som vuxna kan testa hur hälsosamt det lever. Testen är enkelt och sinnligt utformad. Detta test marknadsfördes bl.a. elektroniskt på de stora danska dagstidningarnas Internetversioner. Vidare annonserade man i olika veckotidningar om testet. Sommaren 2007 hade 48 000 danskar genomfört testet.

http://kidshealth.org/kid/ kan tjänstgöra som en webbsida som har anpassat sig efter olika målgrupper, dvs. barn, tonåringar samt föräldrar. Man beskriver sig själv på följande sätt:

KidsHealth is the largest and most-visited site on the Web providing doctor-approved health information about children from before birth through adolescence. Created by The Nemours Foundation's Center for Children's Health Media, the award-winning KidsHealth provides families with accurate, up-to-date, and jargon-free health information they can use. KidsHealth has been on the Web since 1995 - and has been accessed by about half a billion visitors. On a typical weekday, more than 500,000 visitors access KidsHealth's reliable information.

KidsHealth has separate areas for kids (http://kidshealth.org/kid/), teens (http://kidshealth.org/teen/), and parents (http://kidshealth.org/ parent/) - each with its own design, age-appropriate content, and tone. There are literally thousands of in-depth features, articles, animations, games, and resources - all original and all developed by experts in the health of children and teens.

Physicians and other health experts review all content before it's published on KidsHealth. All content is re-reviewed on a regular basis (about every 1 to 3 years, or more frequently if needed). You can find the most recent review date and the name of the expert reviewer(s) at the end of each article. You can learn more about how we create our content by 
visiting our editorial policy (http://kidshealth.org/parent/kh_misc/ editorial_policy.html) page.

Samma organisation har en länk som är mer inriktad till ungdomar http://kidshealth.org/teen/ - och här finns exempel på "food och fitness” . Sidan är intressant att studera eftersom de i sina budskap rörande fysisk aktivitet och matvanor inte nämner ohälsa specifikt, dvs. man fokuserar på det som faktiskt berör unga, t.ex. hur jag blir snygg i baddräkten till sommaren. Man har alltså snarare en kosmetisk argumentering än en medicinsk, vilket är en strategi att föredra när målgruppen är tonåringar.

www.klaraklok.no är en norsk sida som bl.a. har information om olika hälsofrågor. Det norska Helsedirektoratet står bakom sidan och intentionerna är säkert de bästa, men det är ytterst tveksamt on någon ung person helt frivilligt skulle besöka sida, eller om de av en slump fick upp den skulle stanna kvar.

En traditionell hälsowebsida kan den Australienska sidan www.cyh. com/Default.aspx?p=1 sägas vara. Sidan är indelad i Parent and childs health, kids health, teen health and young adult health. De olika sidorna skiljer sig tydligt åt när det gäller design och språk. Sidan är återigen ett exempel på s.k. efterfrågestyrd information.

www.kidshealth.org/teen/food_fitness/dieting/obesity.html kan sägas vara den amerikanska varianten av ovanstående webbsida. Det intressanta är dock att man även här har olika utformning samt språk/tilltal beroende på om målgruppen är barn, tonåringar eller vuxna.

Flera amerikanska, brittiska organisationer som berör övervikt/fetma vänder sig huvudsakligen till vuxna via webbsidorna. På dessa webbsidor kan man engagera barn via skolan etc. (www.youthinformation.com/ Templates/Internal.asp?NodeID=90276, www.nhsdirect.nhs.uk/, www.kids. nsw.gov.au/kids/ourwork/participation/resources/obesitysummit.cfm).

Liknande sidor finns även i Sverige, dvs. man vill nå de unga men försöker via s.k. vidareinformatörer såsom skolpersonal m.fl. Exempel på detta är bl.a. www.skolmatensvanner.org, www.mjolkframjandet.se, www.ica.se. www.braskolmat.se. Kampanjer som har liknande upplägg finns det således en hel del av och i detta sammanhang kan den av Statens Folkhälsoinstitut i Sverige - Sätt Sverige i rörelse - särskilt nämnas (www.fhi.se). Denna kampanj byggde på olika aktiviteter och olika målgrupper, såsom skolelever, arbetsplatser etc. Nationellt centrum för främjande av god hälsa hos barn och ungdom (www.oru.se/ncff) som är en svensk myndighet har satsat på att engagera vuxna som sedan ska engagera barn. Aktiviteter såsom gå och cykla till skolan, dans i skolan och maten i skolan är några exempel på NCFF:s verksamheter.

www.kids.nsw.gov.au/kids/thezone.cfm är ett exempel på en webbsida som är interaktiv med huvudsakligen spel och som fokuserar på barns hälsa. Hur välbesökt sidan är vet vi dessvärre ingenting om. 
www.obesitydiscussion.com är ett kommersiell forum som erbjuder gratis medlemskap och möjligheten att skriva inlägg, frågor etc. Det är även mycket reklam på sidan.

Sammanfattningsvis kan vi konstatera att det är få interaktiva webaktiviteter som specifikt handlar om barn, unga, mat och fysisk aktivitet, vilket inte var fallet för ämnesområdet alkohol och droger. De s.k. allmänna hälsowebsidor är ofta efterfrågestyrda, dvs. sidorna når enbart de som redan har ett problem och är väl medvetna om detsamma. I det nästföljande avsnittet kommer studiens resultat att sammanfattas och de frågor som ställdes inledningsvis kommer att besvaras. 



\section{Vilka lärdomar kan dras?}

I detta avslutande avsnitt ska de frågor som ställdes inledningsvis besvaras, nämligen:

- Vilka organisationer (statliga och NGOs) i Norden, Europa och annorstädes använder redan s.k. nya medier i sitt hälsokommunikativa arbete?

- Vilka erfarenheter har man dragit av användandet av nya och interaktiva medier? Finns effektutvärderingar genomförda?

- Hur förhåller sig användandet av nya medier såsom webbsidor, communities på Internet visavi "gamla” beprövade metoder såsom användandet av skolan, idrottslärare etc. som vidareinformatörer?

- Kommer användandet av nya medier att öka i hälsoarbetet eller finns det anledning att återgå till "gamla" beprövade metoder såsom undervisning i skolan etc.

För det första kan vi konstatera att en rad olika myndigheter och NGO:s använder sig av olika interaktiva medier - och då huvudsakligen Internet - i sitt hälsoförebyggande arbete. Vid en genomgång av de aktiviteter som genomförs tycks det mesta vara rent slentrianmässigt användande av kanalen Internet. Det finns få för att inte säga, inga aktörer, som tycks ha genomfört grundläggande mål- och målgruppsanalyser innan man har byggt och sjösatt sina Webbsatsningar. Det finns inte heller några regelmässiga utvärderingar genomförda förutom eventuell besöksstatistik. Undantaget härifrån är den svenska Alkoholkommittén (se ovan). Vi vet med andra ord väldigt lite om vilka effekter de olika satsningarna har och har haft på målgruppens beteenden. $\AA$ andra sidan kan man hävda att det troligtvis inte är särskilt kostnadskrävande att bygga en webbsida i jämförelse med t.ex. personlig rådgivning.

Ovan har exempel getts på mer eller mindre fantasifulla webbsidor som säkert kan upplevas attraktiva för de unga. Problemet är, vilket har nämnts ovan vid flera tillfällen att flertalet av dessa webbsidor är s.k. efterfrågestyrda. Detta innebär att människor först när de känner till ett problem, eller är sjuka blir aktiva informationssökare och då behövs i princip ingen tjusig eller speciell layout. Den aktivt informationssökande individen tar till sig budskapet ändå. Grälla färger och attraktiv layout behövs för att skapa uppmärksamhet för ett specifikt problem. När det gäller kost och fysisk aktivitet och målgruppen är barn och unga i allmänhet är det därför ytterst tveksamt om Internet - oavsett hur mycket spel och chattfunktioner som finns - kan vara effektivt. En ännu inte överviktig ung människa har med andra ord inget behov av att äta rätt och 
öka sin fysiska aktivitet för att man eventuellt ska förbli frisk och få ett längre liv. Budskap som har en möjlighet att utlösa den önskade handlingen kännetecknas dels av ett enkelt innehåll, dels av att de levereras tidsoch rumsmässigt så nära handlingen som möjligt; s.k. point of action display. Exempel på insatser av detta slag är dekaler, affischer eller s.k. banners på olika webbsidor. Detta innebär i klartext att dekaler skulle kunna sättas upp på snabbmatskedjor eller vid butikernas chipshyllor med uppmaningar om att äta frukt istället för att behålla formen. Problemet med detta exempel är att vare sig snabbmatskedjor eller livsmedelhandlare skulle gå med på detta. På olika communities på Internet finns redan denna strategi. Om jag t.ex. skriver följande till mina Internetvänner; Jag skulle så gärna vilja shoppa i helgen, men jag har inga pengar, så kommer det snabbt upp en eller flera banners på lånemöjligheter. Lek därför med tanken om jag skriver följande; Jag skulle så gärna vilja bli smal och snygg för att komma i den urläckra bikinin, och så ploppar en eller flera banners upp med följande budskap; promenera minst 30 minuter varje dag. Oetiskt - kanske, men troligtvis betydligt mer effektivt än de tämligen lama Internetsatsningar vi hittills har sett inom hälsoområdet. Facebook beskriver bl.a. denna strategi på följande sätt: Promote your website or Facebook with highly-targeted advertising. Make your ads even more effective by attaching them to News Feed stories about the users's friends (www.facebook.com/business/+beacon). Även Yahoo och Google säljer tjänsten "riktad marknadsföring”, dvs. erbjuder annonsörer att nå människor som aktivt söker efter information om specifika produkter. Googles kallar detta koncept för AdWords (http://searchmarketing.yahoo.com /sv_SE/srch/index.php, www.google.se/intl/sv/ads). Självklart är detta en guldgruva för annonsörer, eftersom det möjliggör att skräddarsy reklamen för varje enskild användare. Kort sagt: Den deprimerande får reklam för antidepressiva medel, bantaren får reklam för bantingspiller, den fattige om sms-lån osv. Huruvida detta förfaringssätt är integritetskränkande eller inte för medborgarna är en debatt som bör hållas levande och framförallt bör kännedomen om dessa strategier ökas bland konsumenterna.

Denna studies övergripande syfte var att utröna om de kanaler som används av kommersiella sändare visavi barn och unga även kan användas i icke-kommersiella sammanhang för att få mottagarna att aktivt välja hälsosamma livsstilar. Skillnaden mellan kommersiell och ickekommersiell marknadsföring är att den förra ofta uppmuntrar människor att göra något, t.ex. köpa en produkt, medan den icke-kommersiella marknadsföringen ofta går ut på att hindra människor att göra något, te.x låta bli att röka, äta sötsaker eller åka i en varm buss. Detta är alltså lättare att via marknadsföring få människor att göra något än att få dem att låta bli. Belöningen vid kommersiell marknadsföring, dvs. om man följt budskapet kommer omedelbart - man får det man köpt i sin hand. Belöningen för att man cyklar till skolan i ur och skur och äter grönsaker och frukt är inte omedelbar. Vi människor har ofta andra prioriteringar än vad 
som är fallet för hälsoupplysare, dvs. ett framtida hot rörande ohälsa har ofta mindre betydelse än ett närliggande hot och problem i vardagen. Hotet att bli ensam om man inte följer med sin kamrater till hamburgerbaren är alltså betydligt större än att man i framtiden kan drabbas av ohälsa. Majoriteten av människor - såväl unga som gamla - tycker att det är bättre att leva här och nu än att oroa sig för framtiden.

Finns det då anledning att återgå till "gamla” beprövade metoder såsom undervisning i skolan m.m när det gäller kost och fysisk aktivitet? På denna fråga vill jag svara både ja och nej. Det hälsoförebyggande arbete som kan bedrivas och bedrivs av skolan, fritidsledare, idrottsförbund etc. bör fortsätta och givetvis erhålla stöd avseende ekonomiska resurser, metoder m.m. samtidigt som man ska satsa på "marknadsföring” i de nya medierna. Om det sistnämnda ska göras är det dock viktigt att "de goda" aktörerna finns på de webbsidor där barn och unga finns, och här gäller det att vara ständigt påläst, såtillvida det som är dagens stora grej kan vara morgondagens flopp. Att vara ständigt uppdaterad och föränderlig är i vårt medielandskap numera ett honnörsord. Ovan nämndes hur olika kommersiella aktörer använder sig av s.k. krokar på alla tänkbara webbsidor. Vill myndigheter och NGO:s vara med i detta lopp så måste denna förmåga att lägga ut krokar utvecklas. Låt mig avsluta och sammanfatta i ett antal punkter vad som kännetecknar ett lyckat folkhälsoarbete, eller om man hellre vill folkhälsokampanjer. Med lyckat arbete menar jag här att de aktiviteter som man företar ska ha någon form av effekt på målgruppen:

- använd flera olika typer av medier, dvs. radio, TV, broschyrer, Internet osv.

- kombinera masskommunikation med interpersonell kommunikation, t.ex. små-grupps aktiviteter, rådgivning etc.

- genomför en noggrann målgruppsanalys

• använd "kändisar" för att höja uppmärksamheten för kampanjens ämne

- repetera ständigt enkla budskap

- förespråka det positiva med en beteendeförändring snarare än det negativa med det felaktiga beteendet, dvs. framkallande av rädsla anses inte användbart som kampanjstrategi

- förespråka närliggande belöningar snarare än att man ska undvika avlägsna negativa konsekvenser av ett beteende

- engagera s.k. nyckelpersoner/grupper från medieorganisationerna och myndigheter i kampanjarbetet

- ha en noggrann tidsplanering

- använd formativa utvärderingstekniker för att värdera och förbättra kampanjen under planeringen och under genomförandefasen

- ha mätbara mål som uttrycks i form av beteendeförändringar

- använd såväl kommersiell som icke-kommersiell marknadsföring 
- sätt in pedagogiska budskap i ett underhållande sammanhang

- blunda inte för de större sociala sammanhang som påverkar det hälsoproblem som kampanjen handlar om

- samorda med aktiviteter såsom rådgivning, telefonlinjer etc.

- använd en psykografisk målgruppsindelning (efter attityder, värden, m.m.) snarare än en demografisk indelning (efter ålder, kön m.m.).

- använd personer som har ett starkt interpersonellt inflytande på målgruppen

- var noggrann vid val av förebilder (t.ex. om kändisar är med i en kampanj mot droger är det viktigt att dessa är totalt drogfria själva)

- ge anvisningar om hur man ska agera för att undvika att problem uppstår om man använder sig av budskap som innehåller skräck eller rädsla

- inse att det inte räcker med att enbart annonsera, utan förstå att man bör kombinera olika kampanjaktiviteter

- använd nyhetsmedierna för att öka synligheten

- bygg på de kunskaper och värderingar hos målgruppen som hindrar dem från att uppta det önskade beteendet

- bygg på de fördelar som målgruppen kan vinna på att uppta det önskade beteendet, vilket i sin tur ska bygga på existerande önskningar och behov hos målgruppen

- fokusera på omedelbara och sannolika konsekvenser av ett hälsosamt beteende

- förtesta budskap på målgruppen för att försäkra sig om att de tolkas på det sätt som avses. 


\title{
Referenser
}

Alkoholkommittén 2001-2007. Slutrapport. Stockholm.

Brown, J.D. och Einsiedel, E.F. (1990). Public Health Campaigns: Mass Media Strategies. In Ray, E.B. och Donohew, L. (1990). Communication and Health. Systems and Applications. Hillsdale: Lawrence Erlbaum Associates, Publishers

Jarlbro, G (2004) Hälsokommunikation en introduktion. 2:a upplagan. Lund: Studentlitteratur.

Kurth, T (1981) Local Campaigns and Approaches by the Forest Community. I Rice, R.E \& Paisley, W.J (red.) Public Campaigns. Newbury Park: Sage.

Lefebvre, R.C. och Flora, J.A. (1993). Social Marketing and Public Health Intervention. In Thornton, B.C. och Kreps, G.L. (red.) Perspectives on Health Communication. Illinois: Prospect Heights.

McQuail, D (1984) Mass Communication Theory. London: Sage.

Mediebarometern 2007. Göteborgs universitet, NORDICOM- Sverige, nr 1, 2008.

Medierådet (2006) Ungar \& medier 2006. Fakta om barns och ungas användning och upplevelser av medier. Stockholm: Medier rådet.
Nordic Council of Ministers (2006) Health, food and physical activity. ANP 2006: 745.

Nord (2008) Prinsessmuffins och chokladägg. En analys av livsmedelsreklam till barn. Nord 2008:003.

Palm, L och Sandberg, H (2004) Strategier för hälsokommunikation och deras användbarhet. En genomgång av forskningsläget. Statens Folkhälsoinstitut, Sverige.

Reardon, K.K. (1989). The Potential Role of Persuasion in Adolescent Aids Prevention. In Rice, R.E. och Atkin, C.K. (red.) Public Communication Campaigns. Newbury Park: Sage Schultz Jörgensen, S och Viderskov, K (2008) Usund indflydelse. En kortlaeggning av dansk och international viden om marknadsforing af usunde födevarer rettet mod barn. Kontrabande \& Danmarks Medie- og Journalisthögskole.

Witte, K. (1995). Fishing for Success: Using the Persuasive Health Message Framework to Generate Effective Campaign Messages. In Maibach, E. och Parrot, R.L. (red.) Designing Health Messages. Approaches From Communication Theory and Public Health Practice. London: Sage Publications.

\section{Refererade webbsidor i kronologisk ordning}

\author{
www.infomedica.se, \\ www.sjukvårdsrådgivningen.se \\ www.yad.fi \\ www.drugsmart.com \\ www.glod.com \\ www.junis.org. \\ www.iq.se \\ www.goda.dk \\ www.avogtil.no/ \\ www.diil.no \\ www.parentsusingdrugs.org.uk \\ https://www.barnogunge.no/ \\ www.adf.org.au. \\ www.somazone.com.au \\ www.d-2k.co.uk/ \\ http://talktofrank.com
}


www.adf.org.au.

www.somazone.com.au

www.d-2k.co.uk/

http://talktofrank.com

www.sada.org

www.skateagainstdrugs.org

www.acys.info/about/

www.turningpoint.org.au/

www.drugpoint.org.au/index.htm

http://www.turningpoint.org.au/e\&t/Opie\%20website\%20preview/

Opie\%20website\%20preview.htm.

www.weedfarmer.com/top100/

www.marijuananews.com/blog

www.ama.com.au/youth/code/cannibis.html

www.ungdomar.se

www.projektversus.se

http://www.ur.se/Ung/Amnen/Halsa/.

www.ur.se/Ung/Program/Ramp/

www.ohjelmaopas.yle.fi/sisaltooppaat/lapset/.

www.dr.dk/boern

www.rodasidorna.se

www.ung.no/oss/helse/12390.html

www.matrock.se/-

www.altomkost.dk

http://kidshealth.org/kid/

http://kidshealth.org/teen/

www.klaraklok.no

www.cyh.com/Default.aspx?p=1

www.kidshealth.org/teen/food_fitness/dieting/obesity.html

www.youthinformation.com/Templates/Internal.asp?NodeID=90276

www.nhsdirect.nhs.uk/,

www.kids.nsw.gov.au/kids/ourwork/participation/resources/obesitysummit.cfm www.skolmatensvanner.org

www.mjolkframjandet.se,

www.ica.se

www.braskolmat.se.

www.fhi.se

www.oru.se/ncff

www.kids.nsw.gov.au/kids/thezone.cfm

www.facebook.com/business/+beacon

http://searchmarketing.yahoo.com/sv_SE/srch/index.php

www.google.se/intl/sv/ads 


\section{Summary}

This report has been included as a subproject of the project titled "Realizing Nordic Benefits in Communication under the Nordic Council of Ministers" ("Realisering av Nordisk Nytte i Kommunikation under Nordisk Ministerråd"). The report is based on a desktop study, and its overall purpose is to assess whether the channels being used successfully by commercial broadcasters to reach children and young people can also be used in non-commercial contexts to persuade the recipients to actively choose more healthy lifestyles. The term "young people" in this context refers to people between the ages of 9 and 15, and the focus with respect to health issues is on diet and physical activity. The issues that the study will attempt to address are the following:

- Which organizations (governmental and non-governmental organizations (NGOs)) in the Nordic region, Europe and elsewhere are already using "new media" in their health-related communication activities?

- What experience has been gained from the use of new and interactive media? Have any effect evaluations been carried out?

- How does the use of new media, such as websites and online communities, compare with "old" proven methods such as the use of schools, and physical education (PE) instructors, to relay information?

- Will the use of new media increase in the health field, or are there reasons to return to "old" proven methods, such as instruction in schools, etc?

The overall purpose of the study is not to account for all of the activities being carried out in the areas of diet and physical activity, but rather, to aid in relevant theory building and research with a view to determining appropriate communication strategies for the future. The actual study has been conducted mainly via Internet searches.

The study indicates that a host of different governmental agencies and NGOs are using various interactive media, mainly the Internet, in their preventive health care efforts. A review of the activities being done indicates that most involve purely routine use of the Internet as a channel. There are few actors who appear to have conducted basic target and target group analyses before building and launching their online initiatives. Nor are any regular assessments being conducted, outside of keeping visitor statistics. In other words, very little is known about the effects that these various efforts have had or are having on the behaviour of their 
target groups. On the other hand, it may well be pointed out that building a website is probably not particularly cost-intensive compared with, for instance, providing personal consultation.

The report cites examples of more or less imaginative websites that young people may find attractive. The problem is that the majority of these websites are "demand-based". This means that people do not become active information seekers until they recognize a problem or become ill, at which point no special layout or enticing presentation is really needed. The active information seeker will assimilate the message regardless of presentation. Bold colours and attractive layouts are needed to draw attention to a specific problem. When it comes to diet and physical activity and the target group comprises children and young people, it is therefore extremely doubtful whether the Internet can be effective, no matter how many games and chat functions are available. In other words, a not yet overweight young person has "no need" to inform him or herself about eating right and or becoming physically more active in order to potentially stay healthy and live a longer life. Messages that have the potential to elicit a desired action are characterized partly by having a simple content, and partly by being delivered in the greatest possible chronological and spatial proximity to the desired action, i.e. a "point of action display". Examples of activities of this type include decals, posters and the banners seen on various websites.

The overall purpose of this study was to determine whether the channels being used by commercial broadcasters to reach children and young people could also be used in non-commercial contexts to persuade the recipients to actively choose more healthy lifestyles. The difference between commercial and non-commercial marketing is that the former often encourages people to do something, for example to buy a product, while non-commercial marketing is often intended to deter people from doing something, for example to stop smoking or eating sweets. It is easier to get people to do something via marketing than it is to get to them to refrain from doing something. The rewards associated with commercial marketing, i.e., the rewards that appear immediately if the message gets through, consist in having the purchase in hand. The rewards for bicycling to school in all kinds of weather, or eating fruit and vegetables, are not immediate. We human beings often have priorities that differ from those of health officials, in other words, a future health threat is often less important to us than an immediate threat or problem in our daily lives.

The report also discusses whether there is any reason to return to "old" proven methods such as instruction in schools, etc when it comes to diet and physical activity. The answer to this question is both yes and no. Those preventive health care activities that can be, and are being, carried out by schools, recreation leaders, athletic associations, etc should continue, and should naturally receive support in terms of financial resources 
and methodology, even while investments in "marketing" via the new media are being made as well. With regard to the new media it is, however, important for the information to be accessible on the websites that are frequented by children and young people. In this regard, it is important to always stay current and informed, as today's hot websites can turn into tomorrow's not websites. Staying constantly updated and flexible in our media landscape is now a watchword. The report identifies a number of ways in which various commercial actors are using "hooks" on every conceivable website. If governmental agencies and NGOs want to get in the game, then this ability to deploy such hooks, in other words, to be present on the websites that are being frequented by the target group, will need to be developed. 